\title{
Diseño de hormigón durable
}

\section{Designing concrete for durability}

\author{
A.J. BOYD ${ }^{(*)}$, S. MINDESS $\left({ }^{(*)}\right.$, J.SKALNY ${ }^{(* *)}$ \\ (")Dep. of Civil Engineering, Univ. of Florida, EE UU, (") Dep. of Civil Engineering, Univ. of British \\ Columbia, CANADA, ${ }^{(\cdot)}$ Materials Service Life, Florida, EE UU
}

Fecha de recepción: 18-V-2001

\section{RESUMEN}

Se discuten algunos de los factores que influyen en la durabilidad de las estructuras de hormigón modernas, haciendo énfasis en los problemas causados por el cemento portland. A esto sigue una descripción de algunas cuestiones de interés general de la durabilidad del hormigón tales como la retracción plástica, el ataque por agua de mar y el ataque por sulfatos. Se discuten también las estrategias de los ensayos de durabilidad. Se concluye que para producir hormigones durables se debe adoptar un enfoque holistico de la construcción con hormigón.

\section{SUMMARY}

Some of the factors affecting the durability of modern concrete structures are discussed, with an emphasis on the problems caused by modern portland cements. This is followed by a description of some concrete durability issues of current interest, such as plastic shrinkage, seawater attack, and sulfate attack. The strategies for testing for durability are also discussed. It is concluded that, to produce durable concretes, a holistic approach to concrete construction must be adopted.

\section{INTRODUCCIÓN}

Históricamente, las estructuras de hormigón se han diseñado, ante todo, en base a su resistencia a la compresión. Siempre se consideró que si el hormigón era suficientemente resistente como para soportar las cargas diseñadas, también se comportaría satisfactoriamente en todos los demás aspectos. Por supuesto, cuando se identificaba y comprendía un determinado mecanismo de destrucción (ej: el ataque hielo/ deshielo, ataque por sulfatos, reacción álcaliárido, corrosión por cloruros, etc.), éstos se tenían en cuenta a través de alguna combinación de limitaciones en la composición química del cemento y/o en la relación agua/cemento (w/c). No obstante, incluso hoy día, cuando hay mucha mayor conciencia en torno a los aspectos de la durabilidad, estos factores son muy a menudo

\section{INTRODUCTION}

Historically, concrete structures have been designed primarily on the basis of concrete compressive strength. It was assumed that if the concrete was strong enough to withstand the design loads, it would perform satisfactorily in all other respects as well. Of course, when particular destructive mechanisms were identified and understood (e.g., freeze/thaw attack, sulfate attack, alkali-aggregate reaction, chloride corrosion, and so on), these were taken into account through some combination of limitations on the cement chemistry and/or the water/ cement $(w / c)$ ratio. Nonetheless, even today, when there is much more awareness of durability considerations, these factors are most often considered in concrete mix design only after the 
considerados en el diseño de la mezcla del hormigón, pero solamente después de que éste haya sido diseñado sobre la base de su resistencia a la compresión.

El término Durabilidad se refiere a la capacidad del hormigón para cumplir satisfactoriamente las funciones para las que se diseñó a lo largo de la vida prevista de la estructura (y, a menudo, más allá de ésta). El hormigón es un material intrínsecamente durable. $\mathrm{Si}$ se diseña, produce y mantiene adecuadamente puede durar muchas décadas e incluso siglos. Las estructuras Romanas de dos mil años (tal como el Panteón en Roma y el Pont du Gard en Nîmes, y muchos otros anfiteatros y viaductos que todavía se pueden ver en torno al Mediterráneo) son un testamento de la durabilidad potencial del hormigón.

Sin embargo, desafortunadamente, muchas estructuras modernas de hormigón, no duran tanto, como lo pone en evidencia la continua necesidad de reparar y rehabilitar muchas de nuestras infraestructuras de hormigón. Desde luego algo de esto se puede explicar por las exigencias, mucho más severas, que nosotros fijamos a los hormigones modernos, los entornos especiales en los que esperamos que el hormigón cumpla sus funciones, y la complejidad creciente de los sistemas cementantes en sí mismos. Por otra parte, mucho de esto es debido a una selección inapropiada de materiales, a prácticas constructivas pobres, a falta de entendimiento por parte de los ingenieros que diseñan los diversos ambientes potencialmente destructivos a los que se podrían exponer los hormigones (a pesar de la voluminosa bibliografia existente sobre el tema) y una creciente tendencia a "hacer recortes", con el fin de ahorrar algún dinero.

La subsiguiente discusión versará sobre alguno de los principales factores que influyen en la durabilidad, seguido de un examen de algunos problemas de durabilidad de interés general incluyendo los ataques por agua de mar y sulfatos, y algunas reflexiones sobre cómo ensayar el hormigón para conocer su durabilidad potencial.

\section{PRINCIPALES FACTORES QUE INFLUYEN EN LA DURABILIDAD EN GENERAL}

Tal y como se estableció anteriormente, tradicionalmente se ha mantenido que es la resistencia del hormigón la que determina su durabilidad. Esto, a su vez, implicaría que se puede controlar la durabilidad simplemente controlando la relación a/c (o la relación $\mathrm{a} / \mathrm{cm}$, donde $\mathrm{a} / \mathrm{cm}$ significa la relación del agua respecto del contenido total de material cementante, incluyendo las adiciones). Sin embargo, cada vez está concrete has first been designed on a compressive strength basis.

Durability refers to the ability of concrete to fulfill its design functions satisfactorily throughout the projected life of a structure (and often far beyond this). Concrete is an inherently durable material. If properly designed, produced and maintained, it can last for many decades, and even centuries. Two thousand year old Roman structures (most notably the Pantheon in Rome, and the Pont du Gard at Nîmes, and many other amphitheatres and viaducts still to be seen around the Mediterranean) are a testament to the potential durability of concrete.

Unfortunately, however, many "modern" concrete structures have not fared nearly so well, as is evidenced by the continuing need to repair and rehabilitate much of our concrete infrastructure. Some of this can be explained, of course, by the much more severe demands that we place on modern concretes, the special environments in which we expect concrete to work, and the increasingly complex nature of the cementitious system itself. On the other hand, much of this is also due to an improper choice of materials, poor construction practices, a lack of understanding amongst design engineers (despite the voluminous literature on the subject) of the various potentially destructive environments to which the concrete might be exposed, and an increasing tendency to "cut corners" in order to save a few pennies.

The discussion below will deal with some of the principal factors affecting durability, followed by an examination of several durability problems which are of current interest, including sulfate attack and seawater attack, and some thoughts on how to test concrete for potential deterioration.

\section{PRINCIPAL FACTORS INFLUENCING DURABILITY IN GENERAL}

As stated above, it has traditionally been held that it is the strength of the concrete that determines its durability. This, in turn, would imply that durability can be controlled simply by control of the $w / c$ ratio (or $w / \mathrm{cm}$ ratio, where $w / \mathrm{cm}$ refers to the ratio of water to the total cementitious content, including mineral admixtures). However, it is becoming increasingly clear that this assumption is a fallacy. 
más claro que esta suposición es una falacia. Como ha sido destacado por Sha y colaboradores (1) para diseñar un hormigón durable es necesario considerar al menos, tres criterios -resistencia mecánica, permeabilidad y resistencia a la fisuración-y estos criterios no son todos meramente una función de la relación a/cm. El primero de ellos, la resistencia, está verdaderamente muy controlado por la relación $\mathrm{a} / \mathrm{cm}$. La permeabilidad, sin embargo, está mucho mas relacionada con el contenido total de agua en la mezcla, mientras que la fisuración a edades tempranas parece estar afectada fundamentalmente por la finura y la composición química del propio cemento.

Es bien conocido que los cementos "modernos" (es decir, aquéllos hechos desde 1960), tienen un alto contenido en $\mathrm{C}_{3} \mathrm{~S}$ y una finura superior que los cementos "al viejo estilo" a los cuales reemplazaron (2-4). Mientras que esto ha hecho posible las actuales velocidades de construcción, mucho más rápidas, ello ha traido consigo un precio. La mayor velocidad en el aumento de resistencias implica que la resistencia a compresión a 28 días se puede alcanzar con una relación a/cm superior a la empleada antiguamente. Aun cuando esto puede ahorrar algún dinero a los productores de hormigón, la consecuencia es un hormigón mas permeable y menos durable. A su vez, tales hormigones tienen un módulo elástico superior, una retracción por secado mas alta y una menor capacidad de fluencia, lo que los hace mas frágiles y más susceptibles de fisurarse, sobre todo a edades tempranas. Estos hormigones requieren también un régimen de curado mejor, con el fin de producir una mejor "piel" del hormigón (ver más adelante), pero las buenas prácticas de curado parecen ser "una costumbre que destaca más por su incumplimiento que por su observación".

Es muy improbable que se vuelva a los cementos molidos gruesos y con bajos contenidos en $\mathrm{C}_{3} \mathrm{~S}$. Ello es innecesario y probablemente indeseable. La solución se encuentra más bien en el uso inteligente de todos los materiales disponibles, incluidos los áridos, para producir una mezcla de elevada calidad. Debería recordarse que es relativamente poco el hormigón que hoy día se produce usando cemento portland puro como conglomerante. Con mayor frecuencia, en las mezclas de hormigón moderno se usan una diversidad de adiciones minerales y aditivos químicos. Cenizas volantes, escorias de horno alto granuladas y molidas y humo de sílice son ya de uso común como lo son los agentes reductores de agua y los aireantes.

Verdaderamente, de acuerdo con Nehdi (5), los cementos ternarios y cuaternarios, llegarán a ser cada vez más comunes, no sólo por razones ambientales sino también para la producción de hormigones de altas prestaciones. Combinaciones apropiadas de adiciones
As pointed out by Shah et al. (1), at least three criteria-strength, permeability and cracking resistance-need to be considered for the design of durable concrete, and these are not all merely a function of $w / \mathrm{cm}$. The first of these criteria, strength, is indeed largely controlled by the $w / \mathrm{cm}$ ratio. Permeability, however, is much more closely related to the total water content of the mix, while early age cracking seems to be affected mostly by the fineness and chemical composition of the cement itself.

It is well established that "modern" cements (i.e., those made since about 1960), have both a higher $C_{3} S$ content and a higher fineness than the "oldfashioned" cements that they replaced (2-4). While this has made possible today's more rapid rates of construction, it has come at a price. The higher rate of strength gain means that 28-day compressive strengths can be achieved at a higher $w / \mathrm{cm}$ ratio than formerly. While this may save some money for the concrete producer, the result is a more permeable, and thus less durable concrete. As well, such concretes have higher elastic moduli, an increased drying shrinkage, and a lower creep capacity, making them more brittle and thus more susceptible to cracking, particularly at early ages. These concretes also require a better curing regime in order to produce a better concrete "skin" (see below), but good curing practice seems to be " $a$ custom more honor'd in the breach than the observance".

It is highly unlikely that we will ever return to coarsely ground cements with low $C_{3} S$ contents. This is both unnecessary, and probably undesirable. The solution lies rather in the intelligent use of all of the materials available to produce a high quality mix, including the aggregates. It should be remembered that relatively little of the concrete produced today is made with a pure portland cement binder. More commonly, a variety of mineral and chemical admixtures are used in modern concrete mixtures. Fly ash, ground granulated blast furnace slag, and silica fume are already in common use, as are water reducers and air entraining agents. Indeed, according to Nehdi (5), ternary and quaternary cements will become increasingly common, not only for environmental reasons, but also for the production of high performance concretes. Appropriate combinations of mineral admixtures (supplementary cementing materials) and chemical 
minerales (materiales cementantes suplementarios) y de aditivos químicos debería permitirnos hacer hormigones que combinen la durabilidad de los "viejos" hormigones con el rápido aumento de resistencias de los modernos.

\section{ALGUNAS CUESTIONES SOBRE LA DURABILIDAD DEL HORMIGÓN}

\section{Piel superficial}

La capa superficial o "piel" de una estructura de hormigón juega un importante papel en la durabilidad. Actúa como una primera línea de defensa frente a la entrada de compuestos dañinos y también opone resistencia a mecanismos de daño físico tales como la abrasión, la erosión o la cavitación. Con el fin de que desempeñe adecuadamente sus funciones, esta capa debe poseer baja permeabilidad y alta resistencia. Hay una diferencia importante entre las propiedades de la "piel superficial" del hormigón y aquéllas del conjunto del material. Algunas de estas diferencias están inducidas por el modo en que el hormigón es fabricado o encofrado. Un ejemplo obvio de esto es la ausencia de partículas de árido cerca de la superficie. Kreijger (6) demostró que la zona próxima a la superficie tiene, por sí misma, un menor contenido de áridos $\mathrm{y}$, por tanto, una mayor porosidad que el hormigón subyacente. Este fenómeno ocurre también en las superficies encofradas, pero está acentuado en las acabadas a mano donde una capa de pasta más gruesa es impelida hacia la superficie.

Cuando el hormigón fragua surgen diferencias adicionales. Como consecuencia de la exposición directa al ambiente que le rodea, las reacciones de hidratación del cemento, tanto durante el curado como posteriormente, se ven afectadas en diferentes grados, en función de la proximidad a la superficie. Se ha demostrado (7) que las prácticas pobres de curado en ambientes secos y calurosos pueden producir deterioros en la calidad de la piel superficial, mientras que, al mismo tiempo, apenas tienen efectos sobre la resistencia de la masa del hormigón. Como consecuencia de esto, los ensayos de resistencia tradicionales son incapaces de caracterizar adecuadamente el material de la superficie.

Bentur \& Jaegermann (7) describieron un ejemplo adicional de la falta de idoneidad de los ensayos de resistencias. Compararon hormigones que contenian cenizas volantes con otros ordinarios, todos ellos con igual resistencia nominal, sometidos a varios regímenes de curado en clima caliente y seco. Se encontró que el efecto sobre las resistencias era similar en ambos tipos de hormigones, pero que admixtures should permit us to make concretes which combine the durability of "old" concretes with the more rapid strength gain of modern concretes.

\section{SELECTED CONCRETE DURABILITY ISSUES}

\section{Surface skin}

The surface layer or 'skin' of a concrete structure plays an important role in durability. It acts as the first line of defense against the ingress of deleterious compounds, and also resists physical damage mechanisms such as abrasion, erosion or cavitation. In order to perform its intended duties sufficiently, this layer must possess low permeability and high strength. There is a significant difference between the properties of the surface skin of concrete and those from the bulk concrete. Some of these discrepancies are induced by the way concrete is cast or formed. An obvious example of this is the absence of aggregate particles near the surface. Kreijger (6) showed that the near-surface zone inherently has a lower aggregate content and thus higher porosity than the underlying concrete. This phenomenon occurs at formed surfaces as well, but is accentuated in hand finished surfaces where a thicker layer of paste is worked to the surface.

Further differences appear as the concrete sets. As a consequence of direct exposure to the surrounding environment, both during the curing process and afterward, the hydration reaction itself is affected to different degrees, dependent upon proximity to the surface. It has been shown (7) that poor curing practices in hot, dry weather can induce significant deterioration in the quality of the surface skin while, at the same time, producing very little impact on the strength of the bulk concrete. As a result, traditional strength testing of concrete is unable to properly qualify the surface material.

A further example of the inadequacy of bulk strength testing was also described by Bentur \& Jaegermann (7). Concretes containing fly ash were compared with ordinary concrete mixes, of the same nominal strength, for various curing regimes in a hot dry climate. It was found that the effect on bulk strength was similar between the two types of concrete, but that the fly ash mixes suffered significantly greater detrimental effects when the properties of the surface 
aquéllos que contenían cenizas volantes experimentaban efectos negativos significativamente superiores cuando se evaluaba solamente la "piel superficial". Aunque en la práctica ambos tipos de hormigones se comportarían de modo similar desde un punto de vista estructural, la durabilidad de los hormigones con cenizas volantes será menor.

Un reciente estudio diseñado para encarar la cuestión de la calidad de la capa superficial en superficies moldeadas es la denominada "permeabilidad controlada por el molde" $(8,9)$. Esta aproximación usa un forro de molde especialmente diseñado que actúa como un filtro drenando hacia fuera el agua y el aire, a menudo atrapado en la interfase hormigón/molde, mientras que previene la exudación de las partículas finas del cemento. El resultado es una menor relación agua/cemento en el hormigón próximo a la superficie, generando, a su vez, unas mayores resistencias y menor permeabilidad a los gases y al agua. Tal reducción en la relación agua/cemento mejora directamente la durabilidad del hormigón.

Por lo tanto y aunque explícitamente no suele estar descrito en discusiones sobre la durabilidad del hormigón, la piel del hormigón es crucial para la durabilidad a largo plazo. Sus propiedades juegan un importante papel en la determinación del grado de deterioro de los hormigones expuestos al ataque del agua de mar y al ataque por sulfatos que se describen posteriormente.

\section{Fisuración por retracción plástica}

El fenómeno, normalmente referido como fisuración por retracción plástica, es un caso especial de retracción por secado, y sucede mientras que el hormigón está todavía en estado plástico o en estado no endurecido. Tal fisuración puede ocurrir siempre que la velocidad de evaporación del agua desde la superficie del hormigón sea superior a la velocidad de movimiento de agua hacia la superficie. Estas condiciones producen secados localizados en la superficie del hormigón, retracción y, potencialmente, fisuración. Las fisuras por retracción plástica no son normalmente importantes desde el punto de vista estructural debido a sus pequeñas dimensiones. Son, sin embargo, importantes en tanto en cuanto poseen el potencial de afectar a la durabilidad de una estructura de hormigón por el elevado incremento de la permeabilidad total de la superficie del hormigón, lo que permite la entrada de agua cargada de compuestos nocivos a mucha mayor velocidad.

Es sabido que la fisuración por retracción plástica es un problema que se da en climas cálidos y secos. skin alone were evaluated. Though, in the field, both concretes should perform similarly from a structural point of view, the durability of the fly ash concretes will be inferior.

A fairly recent development designed to address the issue of surface skin quality in formed surfaces is controlled permeability formwork $(8,9)$. This approach uses a specially designed form liner which acts like a filter, draining away the water and air normally trapped at the concretelformwork surface while preventing the cement fines from following. The result is a lower water/cement ratio in the nearsurface concrete, leading to higher strength and lower permeability to gas and water. Such a reduction in water/cement ratio directly improves the durability of the concrete.

Thus, although it is not often addressed explicitly in discussions of concrete durability, the concrete skin is crucial to the long-term durability. Its properties play a large part in determining the degree of deterioration of concrete exposed to the seawater and sulfate attacks described below.

\section{Plastic shrinkage cracking}

The phenomenon commonly referred to as plastic shrinkage cracking results from a special case of drying shrinkage, and occurs while the concrete is still in its plastic or unhardened state. Such cracking can occur whenever the rate of evaporation of water from the concrete surface is higher than the rate of bleed water movement to the surface. These conditions result in localized drying of the concrete surface, shrinkage and, potentially, cracking. Plastic shrinkage cracks are not normally structurally significant due to their small dimensions. They do, however, have the potential to significantly affect the durability of a concrete structure by dramatically increasing the gross permeability of the cover concrete, thus allowing ingress of water-borne deleterious compounds at much higher rates.

It is common knowledge that plastic shrinkage cracking is a problem in hot dry weather. Less well 
Menos conocido es, sin embargo, el hecho de que este problema puede también aparecer a temperaturas bajas y puede, realmente, llegar a ser muy severo a bajas temperaturas cuando se dan ciertas condiciones (10).

Se pueden producir intensas condiciones de evaporación en días fríos y secos y la más lenta velocidad de hidratación da lugar a que el hormigón, en estado plástico, esté expuesto a tal evaporación durante un largo período de tiempo. Adicionalmente, el calor generado por las reacciones de hidratación tiende a templar el aire en las inmediaciones de la superficie, reduciendo su humedad relativa y aumentando, entonces, su potencial de evaporación. Este aire húmedo y templado asciende y es rápidamente reemplazado por otro, frío y seco, creando un régimen cíclico de secado que aumenta el problema.

Lerch (11) desarrolló un nomograma diseñado para permitir la determinación de la velocidad de evaporación de agua esperada desde la superficie del hormigón, en función de un número de factores que incluyen la temperatura y la humedad relativa del aire, la temperatura del hormigón y la velocidad del viento. Esta aproximación fue posteriormente adoptada por el American Concrete Institute para su inclusión en el Manual de Práctica relativo al curado del hormigón (12). $\mathrm{ACI}$ sugiere que se requieren medidas protectoras cuando la evaporación exceda a $1 \mathrm{~kg} / \mathrm{m}^{2} / \mathrm{h}$ pero advierte que la fisuración por retracción plástica puede ocurrir a velocidades de evaporación tan bajas como $0,5 \mathrm{~kg} / \mathrm{m}^{2} /$ h. Aunque el nomograma de Lerch es aplicable a mezclas de hormigón tradicional, falla al dar razón sobre cuestiones que tienen un impacto significativo en la velocidad de exudación del hormigón, tales como las bajas relaciones agua/cemento y los altos contenidos de cemento, o la inclusión de materiales cementantes adicionales y de ciertos aditivos químicos (10). Ya que la fisuración por retracción plástica está directamente relacionada con el equilibrio entre la exudación y la evaporación del agua, el efecto de estos factores debe ser considerado cuando se decida sobre un régimen de curado adecuado.

Saeles y Hover (13) manifiestan que la velocidad de evaporación no es realmente el factor dominante en la fisuración por retracción plástica, y que las propiedades de la mezcla de hormigón y las técnicas de acabado tienen una influencia mayor. Ellos mantienen que una reducción en el volumen de la pasta de hormigón, que puede ser alcanzada con aditivos reductores de agua, realmente ayuda a reducir la fisuración por retracción plástica. Su punto de vista respecto a la menor importancia de la velocidad de evaporación es apoyado por Samman et al. (14), quienes demostraron que hormigones con relaciones agua/cemento mas bajas muestran menores pérdidas de known, however, is the fact that this problem can also occur at cold temperatures and can actually be much more severe at lower temperatures when certain conditions exist (10). Severe evaporation conditions can develop on cold dry days and the slower hydration rate results in the concrete being exposed to such evaporation for a longer period of time in the plastic state. Additionally, the heat generated by the hydration reaction tends to warm the air immediately above the surface, reducing its relative humidity and thus increasing evaporation potential. This warm moist air rises and is quickly replaced by cold dry air, creating a cyclic drying regime that further amplifies the problem.

Lerch (11) developed a nomograph designed to allow determination of the expected rate of water evaporation from the concrete surface, depending upon a number of factors including air temperature and relative humidity, concrete temperature, and wind velocity. This approach was later adopted by the American Concrete Institute for inclusion in their code of practice related to curing of concrete (12). ACI suggests that protective measures are required when the evaporation rate exceeds $1.0 \mathrm{~kg} / \mathrm{m}^{2} / \mathrm{hr}$ but allows that plastic shrinkage cracking may occur at evaporation rates as low as $0.5 \mathrm{~kg} / \mathrm{m}^{2} / \mathrm{hr}$. Though the Lerch nomograph is applicable to traditional ordinary concrete mixes, it fails to account for issues which have a significant impact on the bleeding rate of concrete, such as low water-cement ratios and high cement contents, or the inclusion of supplementary cementing materials and certain chemical admixtures (10). Since plastic shrinkage cracking is directly related to the equilibrium between bleed water and evaporation, the effect of these issues must be considered when deciding upon a proper curing regime.

Saeles and Hover (13) claimed that evaporation rate is not actually the dominating factor in plastic shrinkage cracking, and that the properties of the concrete mix and the finishing technique have a greater influence. They go on to state that a reduction in the paste volume of the concrete, as can be achieved with water-reducing admixtures, actually helps to reduce plastic shrinkage cracking. Their view regarding the lesser importance of evaporation rate is supported by Samman et al. (14), who showed that lower water-cement ratio concretes actually exhibit lower cumulative water losses and lower maximum evaporation rates than ordinary 
agua acumulativas y menores velocidades máximas de evaporación que hormigones ordinarios pero que están todavía sometidos a mayores grados de fisuración por retracción plástica. De hecho, los hormigones con relaciones agua/cemento bajas muestran una fisuración por retracción plástica a velocidades de evaporación muy por debajo de los límites del ACI, mientras que los hormigones ordinarios no se fisuran a velocidades muy superiores a aquel límite.

Soroka y Ravina (15) comunicaron un incremento de retracción plástica, acompañado por una reducción de la resistencia a la tracción a edades tempranas, como una consecuencia directa del uso de aditivos retardadores. Ambos efectos contribuyen directamente a aumentar la fisuración por retracción plástica.

Un estudio sobre el efecto de hormigones con cementos de adición (16) mostró que la inclusión de cenizas volantes y, en mayor medida, de escorias de horno alto, produce un aumento importante en la fisuración por retracción plástica, si bien pequeñas sustituciones de humo de sílice (i.e. $10 \%$ o menos) tienen un efecto pequeño. La mayor incidencia de fisuras en los hormigones con escoria de horno alto fue atribuida a un efecto secundario de reducción de la resistencia a flexión del hormigón, junto con el aumento de la retracción plástica. Soroka y Ravina (15) también informaron de un efecto similar sobre la retracción plástica cuando la sustitución se hace por cenizas volantes.

La discusión anterior indica que en los hormigones modernos, la fisuración por retracción plástica es una función de otros factores además de la velocidad de evaporación de una mezcla de hormigón. Muchas otras cuestiones tienen que ser también consideradas con el fin de eliminar efectivamente el riesgo de fisuración por retracción plástica siendo, esta aproximación global, adoptada en la etapa de diseño de la mezcla.

\section{Ataque por sulfatos}

El daño del hormigón por sulfato es poco común pero es de interés por su complejidad química y física y la variedad de condiciones externas que podrían afectarle. Por estas razones, el deterioro del hormigón por sulfatos es un ejemplo muy bueno sobre el cual demostrar la importancia de un enfoque global en torno al diseño durable, a los métodos de ensayo y a la normalización.

Los procesos químicos por los cuales transcurre el deterioro de los componentes del hormigón debido a sulfatos son numerosos y complejos, e implican reacciones del anión sulfato, $\mathrm{SO}_{4}{ }^{2-}$, con los concretes but are still subject to higher degrees of plastic shrinkage cracking. In fact, the low watercement ratio concretes exhibited plastic shrinkage cracking at evaporation rates well below the $A C I$ limits, while ordinary concretes did not crack at rates much higher than the limit.

Soroka and Ravina (15) reported an increase in plastic shrinkage, accompanied by a reduction in early tensile strength, as a direct result of the use of retarding admixtures. Both of these effects directly contribute to increased plastic shrinkage cracking.

A study into the effect of blended cement concretes (16) showed that the inclusion of fly ash and, to an even greater extent, blast furnace slag results in a significant increase in plastic shrinkage cracking, though low replacements of silica fume (i.e., $10 \%$ or less) have very little effect. The higher incidence of cracking in the blast furnace slag concretes was attributed to a secondary effect of reducing the tensile strength of the concrete in addition to the increase in plastic shrinkage. Soroka and Ravina (15) also reported a similar effect of fly ash replacement on plastic shrinkage.

The forgoing discussion indicates that, for modern concretes, plastic shrinkage cracking is a function of more than just the evaporation rate of a concrete mix. Many other issues must also be considered in order to effectively eliminate the potential for plastic shrinkage cracking and this global approach should be adopted during the mix design stage.

\section{Sulfate attack}

Concrete damage by sulfates is uncommon but is of interest because of its chemical and physical complexity, and the variety of external conditions that might affect it. For these reasons, sulfate deterioration of concrete is a very good example on which to demonstrate the importance of a global approach to durability design, testing, and standardization.

Chemical processes involved in deterioration of concrete components by sulfates are numerous and complex, and involve reactions of the sulfate anion, $\mathrm{SO}_{4}^{2-}$, with concrete liquid phase (pore solution) 
componentes de la fase líquida del hormigón (la solución de los poros) así como con el hidróxido cálcico $(\mathrm{CH})$, silicato cálcico hidratado $(\mathrm{CSH})$ y el monosulfato (AFm) en la pasta endurecida para formar yeso $\left(\mathrm{C} \overline{\mathrm{S}} \mathrm{H}_{2}\right)$ o etringita (AFt). Bajo ciertas condiciones ambientales pueden formarse sulfato de sodio, $\mathrm{Na}_{2} \mathrm{SO}_{4} \cdot 10 \mathrm{H}_{2} \mathrm{O}$, u otras sales y experimentar recristalizaciones repetidas. Bajo diferentes condiciones otros aniones, tal como $\mathrm{CO}_{3}{ }^{2-}$, pueden estar también implicados (ej. formación de taumasita). Los cationes acompañantes pueden o no causar un daño adicional. Un caso particular es la presencia de iones $\mathrm{Mg}^{2+}$ en la solución de los poros, procedente de los suelos y de las aguas del terreno y, ocasional pero raramente, de los componentes del cemento. Los iones $\mathrm{Mg}^{2+}$ pueden reaccionar con el $\mathrm{CSH}$ para formar brucita o gel de sílice amorfo de modo que, simultáneamente con las reacciones del anión sulfato, llevan a la destrucción del material cementante primario del hormigón. Se cree que todas estas reacciones se producen a través de disoluciones. Una revisión de los procesos químicos más importantes del deterioro de hormigones por sulfatos se da en la Tabla 1 (17).

La bibliografia menciona, ocasionalmente, los llamados ataques físicos por sulfatos o cristalización de sales sulfáticas, refiriéndose a la formación y repetida recristalización del sulfato sódico decahidrato (mirabilita), y separándolo artificialmente del ataque por sulfatos (ej. (18)). Nosotros consideramos esto incorrecto, por las siguientes razones:

a) La cristalización y recristalización de sales a partir de disoluciones es un proceso químico similar a aquél de formación del hidróxido cálcico, yeso, o etringita. La formación y repetida recristalización de $\mathrm{Na}_{2} \mathrm{SO}_{4} \cdot 10 \mathrm{H}_{2} \mathrm{O}$ (mirabilita) a tenardita no es un proceso físico per se, sino un proceso químico con consecuencias físicas que conduce a la destrucción de la cohesividad de las pastas por repetidas expansiones de volumen. La reacción es más a menudo observable en zonas áridas con cambios frecuentes de temperatura y humedad que conducen a la hidratación y deshidratación (procesos químicos) del sulfato sódico formado.

b) Frecuentemente se observa la cristalización de sales en forma de eflorescencias sobre losas de hormigón expuestas a aguas subterráneas que contienen sulfatos. Con frecuencia esta observación es típica en hormigones de baja densidad y alta permeabilidad (agua/cemento por encima de 0,6), colocados en zonas donde se producen cambios de humedad y temperatura entre el día y la noche. Cuando la superficie externa del hormigón se seca, aparecen components as well as with calcium hydroxide (CH), calcium silicate hydrate (CSH), and monosulfate (an AFm phase) in the hardened paste to form gypsum $\left(\mathrm{C} \overline{\mathrm{S}} \mathrm{H}_{2}\right)$ or ettringite (an AFt phase). Under certain field conditions sodium sulfate, $\mathrm{Na}_{2} \mathrm{SO}_{4} \cdot 10 \mathrm{H}_{2} \mathrm{O}$, or other salts may form and undergo repeated recrystallization. Under different conditions, other anions, such as $\mathrm{CO}_{3}^{2-}$, may also be involved (e.g. formation of thaumasite). The accompanying cations may or may not cause additional damage. A case in point is the presence of $\mathrm{Mg}^{2+}$ ions in the pore solution, originating primarily from soils and ground water and, occasionally but rarely, from cement components. $\mathrm{Mg}^{2+}$ ions may react with $\mathrm{CSH}$ to form brucite or amorphous silica gel thereby, simultaneously with the sulfate anion reactions, leading to destruction of the primary cementing material in concrete. All these reactions are believed to be through-solution reactions. An overview of the chemical processes relevant to sulfate deterioration of concrete is given in Table I (17).

Occasionally, the literature mentions so-called physical sulfate attack or sulfate salt crystallization, referring to the formation and repeated recrystallization of sodium sulfate decahydrate (mirabilite), and artificially separating it from "sulfate attack" (e.g., (18)). We consider this incorrect for several reasons:

a) Crystallization and recrystallization of salts from solution is a chemical process similar to that of formation of calcium hydroxide, gypsum or ettringite. $\mathrm{Na}_{2} \mathrm{SO}_{4} \cdot 10 \mathrm{H}_{2} \mathrm{O}$ formation and repeated recrystallization of mirabilite to thenardite is not a physical process per se, but a chemical process having physical consequences, namely leading to destruction of the paste cohesiveness by repeated volume expansion. The reaction is most often observable in arid areas with frequent temperature and humidity changes leading to hydrationdehydration (chemical process!) of the formed sodium sulfate.

b) Salt crystallization is frequently observed in the form of efflorescence on concrete slabs exposed to sulfate-containing ground water. More often that not, this observation is typical for low-density, highpermeability concrete ( $w / \mathrm{cm}$ above 0.6$)$ placed in areas with day-night changes in temperature and humidity. As the external surface of concrete dries, efflorescing material deposits on the surface and additional pore solution is transported to the 
eflorescencias sobre la misma y, debido a fuerzas capilares, se produce el transporte de la disolución que rellena los poros hacia el exterior. En función de las condiciones micro ambientales, los iones sulfato transportados pueden reaccionar con los componentes de la pasta de cemento alterando la microestructura de la pasta y conduciendo al daño físico. Tales alteraciones de la microestructura han sido ya demostradas (19).

Los procesos físicos producidos por las reacciones químicas previamente descritas incluyen cambios en el volumen (expansión), desprendimientos, fisuración y pérdida de resistencia y módulo elástico, entre otros. La expansión que acompaña en ocasiones al deterioro debido a sulfatos puede conducir, aunque no necesariamente, a un daño mecánico del hormigón; la severidad del daño debido a la expansión depende de la calidad del hormigón (una función del diseño de la mezcla y de su procesado) y de las condiciones ambientales (temperatura y humedad relativa y de sus cambios durante el procesado y el uso). El tipo de cemento usado, aunque importante, es un factor secundario si se le compara con la calidad del hormigón, es decir, su densidad, permeabilidad y calidad de su microestructura (20).

Algunas consideraciones sobre la expansión. Hay numerosas teorías acerca de la expansión y nos gustaría destacar los trabajos de Gartner y Gaidis (21) y Scherer (22), y la revisión hecha por Skalny y Marchand (17). Está claro que la formación de etringita no es, en sí misma, un proceso expansivo. De hecho, su formación a partir del aluminato tricálcico o del monosulfoaluminato e iones sulfato conduce a una retracción química más que a una expansión. Entonces, la presencia de etringita en el hormigón no es un signo de ataque por sulfato, a menos que haya otra evidencia relativa al daño, incluyendo la alteración de la microestructura. Que la formación de etringita conduzca a expansión y posiblemente a daños depende de numerosas condiciones, incluyendo la disponibilidad relativa de las especies iónicas necesarias en un momento determinado, la composición media de la disolución de los poros, la velocidad de nucleación del cristal frente a la velocidad de crecimiento, el estado físico de la pasta (plástico o endurecido; su resistencia), condiciones locales micro-medio ambientales, etc. Las condiciones previamente mencionadas son más importantes que el origen de los sulfatos (internos o externos) o la calidad del cemento.

La expansión de la matriz del hormigón no es la única forma de daño respecto a los sulfatos. Se considera frecuentemente que el llamado reblandecimiento de la pasta es una consecuencia de la formación de yeso o de exposed surface by capillary forces. Depending on the micro-environmental conditions, the transported sulfate ions may react with the bulk cement paste components, thus altering the paste microstructure and leading to physical damage. Such alteration of the microstructure has been demonstrated (19).

Physical processes resulting from the above chemical reactions include volumetric changes (expansion), spalling, cracking, and loss of strength and modulus of elasticity, among others. The expansion occasionally accompanying sulfate-related deterioration may, but need not, lead to mechanical damage to concrete; the severity of the damage due to expansion depends on the concrete quality (a function of mixture design and processing) and the environmental conditions (temperature and humidity, and their changes during processing and use). The type of cement used, whereas important, is of secondary importance when compared to concrete quality, meaning its density, permeability, and quality of the concrete microstructure (20).

A few words about expansion. There are numerous theories of expansion and we would like to draw your attention to the works of Gartner \& Gaidis (21) and Scherer (22), and the overview given by Skalny \& Marchand (17). Let it be clear that formation of ettringite is by itself not an expansive process. As a matter of fact, its formation from tricalcium aluminate or monosulfate and sulfate ions leads to chemical shrinkage rather than expansion. Thus, the presence of ettringite in concrete is not a sign of sulfate attack unless there is other evidence of related damage, including alteration of the microstructure. Whether ettringite formation will lead to expansion and, possibly, damage depends on numerous conditions, including the relative availability of the needed ionic species at a particular time, overall composition of the pore solution, rate of crystal nucleation versus rate of growth, physical state of the paste (plastic versus hardened; its strength, primarily tensile strength), local micro-environmental conditions, etc. The above conditions are more important than the source of sulfate (internal versus external) or the quality of the cement.

Expansion of the paste matrix is not the only form of sulfate-related damage. The so-called paste softening is often considered to be the result of gypsum formation or CSH decomposition by sulfates 
Reacciones de Sulfatos en Sistemas con Cemento Portland ${ }^{1}$ / (Reactions Involving Sulfates in Portland Cement ${ }^{1}$ )

\section{Ataque "fisico" por sulfatos:}

$$
\begin{array}{ccl}
\begin{array}{c}
2 \mathrm{Na}^{-}+\mathrm{SO}_{4}{ }^{2-} \\
\text { (solución/solution) }
\end{array} & \begin{array}{c}
\Longrightarrow \\
\text { (evaporación/evaporation) }
\end{array} & \begin{array}{l}
\mathrm{Na}_{2} \mathrm{SO}_{4} \cdot 1 \mathrm{H}_{2} \mathrm{O} \\
\text { (sólido/solid) }
\end{array} \\
\begin{array}{c}
\mathrm{Na}_{2} \mathrm{SO}_{4} \cdot 10 \mathrm{H}_{2} \mathrm{O} \\
\text { (mirabilita/mirabilite) }
\end{array} & \begin{array}{c}
\text { (recristalizaciones repetidas } \\
\text { (repeated recrystallization) }
\end{array} & \begin{array}{l}
\mathrm{Na}_{2} \mathrm{SO}_{4} \\
\text { (tenardita/thenardite) }
\end{array}
\end{array}
$$

Oxidación de Pirita (conduce a un ataque combinado de sulfatos y ácido sulfúrico)

Pyrite oxidation (leading to combined sulfate and sulfuric acid attack):

$$
\begin{gathered}
\underset{\text { (pirita/pyrite) }}{2 \mathrm{FeS}_{2}+7 \mathrm{O}_{2}+2 \mathrm{H}_{2} \mathrm{O}} \rightarrow 2 \mathrm{FeSO}_{4}+2 \mathrm{H}_{2} \mathrm{SO}_{4} \\
\text { or } \\
4 \mathrm{FeS}_{2}+15 \mathrm{O}_{2}+2 \mathrm{H}_{2} \mathrm{O} \rightarrow 2 \mathrm{Fe}_{2}\left(\mathrm{SO}_{4}\right)_{3}+2 \mathrm{H}_{2} \mathrm{SO}_{4}
\end{gathered}
$$

Reacciones de formación de etringita/Reactions of ettringite formation:

$$
\begin{array}{cc}
\mathrm{C}_{3} \mathrm{~A}+\underset{\text { (yeso/gypsum) }}{3 \mathrm{C} \overline{\mathrm{S}} \mathrm{H}_{2}+26 \mathrm{H}} & \rightarrow \underset{\text { (etringita/ettringite) }}{\mathrm{C}_{6} \mathrm{~A}_{3} \overline{\mathrm{S}}_{3} \mathrm{H}_{32}} \\
\begin{array}{c}
\mathrm{C}_{+} \mathrm{A} \overline{\mathrm{S}} \mathrm{H}_{12}+2 \mathrm{C} \overline{\mathrm{S}} \mathrm{H}_{2}+16 \mathrm{H} \\
\text { (monosulfato/monosulfate) }
\end{array} & \rightarrow \mathrm{C}_{6} \mathrm{~A} \overline{\mathrm{S}}_{3} \mathrm{H}_{32}
\end{array}
$$

(4-calcio 3-aluminato sulfato/

$$
\mathrm{C}_{4} \mathrm{~A}_{3} \overline{\mathrm{S}}+8 \mathrm{C} \overline{\mathrm{S}} \mathrm{H}_{2}+6 \mathrm{CH}+74 \mathrm{H} \rightarrow 3 \mathrm{C}_{6} \mathrm{~A} \overline{\mathrm{S}}_{3} \mathrm{H}_{32}
$$

4-calcium 3-aluminate sulfate)

Formación de yeso/Gypsum formation:

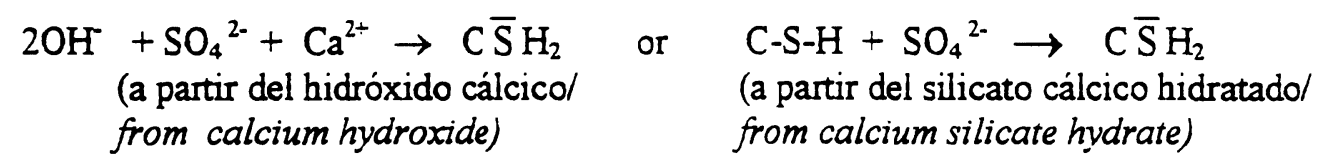

$$
\begin{aligned}
& 2 \mathrm{Na}^{+}+\mathrm{SO}_{4}{ }^{2-}+\mathrm{Ca}^{2+}+\text { aq. } \rightarrow 2 \mathrm{Na}^{-}+\underset{\mathrm{C}}{\overline{\mathrm{S}} \mathrm{H}_{2}+\text { aq. }} \\
& \text { (en presencia de sulfato sódicolin the presence of sodium sulfate) }
\end{aligned}
$$

\footnotetext{
${ }^{1}$ En algunos casos se usa la nomenclatura de la química del cemento $/{ }^{1}$ In some cases the accepted cement nomenclature is used ( $\mathrm{C}-\mathrm{CaO}, \mathrm{S}-\mathrm{SiO}_{\boldsymbol{z}}$ etc.).
} 
Formación de taumasita/thaumasite formation:

$$
\begin{aligned}
3 \mathrm{Ca}^{2+}+ & \mathrm{SiO}_{3}{ }^{2-}+\mathrm{CO}_{3}{ }^{2-}+\mathrm{SO}_{4}{ }^{2-}+15 \mathrm{H}_{2} \mathrm{O} \rightarrow \\
\rightarrow & 3 \mathrm{CaO} \cdot \mathrm{SiO}_{2} \cdot \mathrm{CO}_{2} \cdot \mathrm{SO}_{3} \cdot 15 \mathrm{H}_{2} \mathrm{O} \\
& \text { (taumasita/thaumasite) }
\end{aligned}
$$

Reacciones con el sulfato magnésico/Magnesium sulfate-related reactions:

$$
\begin{aligned}
& \mathrm{Mg}^{2+}+\mathrm{SO}_{4}{ }^{2 \cdot}+\mathrm{Ca}(\mathrm{OH})_{2}+2 \mathrm{H}_{2} \mathrm{O} \rightarrow \mathrm{Mg}(\mathrm{OH})_{2}+\mathrm{CaSO}_{4} \cdot 2 \mathrm{H}_{2} \mathrm{O} \\
& \text { (brucita/brucite) (yeso/gypsum) } \\
& \mathrm{x} \mathrm{Mg}^{2+}+\mathrm{xSO}_{4}{ }^{2-}+\mathrm{xCaO} \cdot \mathrm{SiO}_{2} \cdot \mathrm{aq}+3 \mathrm{xH}_{2} \mathrm{O} \rightarrow \\
& \text { silicato cálcico hidratado/calcium silicate hydrate) } \\
& \rightarrow \times \mathrm{CaSO}_{4}: 2 \mathrm{H}_{2} \mathrm{O}+\mathrm{x} \mathrm{Mg}(\mathrm{OH})_{2}+\mathrm{SiO}_{2} \cdot \mathrm{aq} \\
& \mathrm{CaO} \cdot \mathrm{SiO}_{2} \mathrm{aq}+2 \mathrm{Mg}^{2+}+\mathrm{SO}_{4}{ }^{2-}+2 \mathrm{OH}+2 \mathrm{H}_{2} \mathrm{O} \rightarrow \\
& \rightarrow \mathrm{MgO} \cdot \mathrm{SiO}_{2} \cdot \mathrm{aq}+\mathrm{CaSO}_{4} \cdot 2 \mathrm{H}_{2} \mathrm{O}+\mathrm{Mg}(\mathrm{OH})_{2}
\end{aligned}
$$

Ataque por el agua de mar/Seawater attack reactions:

$$
\begin{aligned}
\mathrm{Mg}^{2+}+\mathrm{Ca}(\mathrm{OH})_{2} & \rightarrow \mathrm{Mg}(\mathrm{OH})_{2}+\mathrm{Ca}^{2+} \\
\mathrm{CO}_{2}+\mathrm{Ca}(\mathrm{OH})_{2} & \rightarrow \mathrm{CaCO}_{3}+\mathrm{H}_{2} \mathrm{O} \\
\mathrm{CO}_{2}+\mathrm{CaO} \cdot \mathrm{SiO}_{2} \cdot \mathrm{aq} & \rightarrow \mathrm{CaCO}_{3}+\mathrm{SiO}_{2} \cdot \mathrm{aq} \\
\mathrm{CaO}^{2} \mathrm{SiO}_{2} \mathrm{aq} & +\mathrm{Mg}^{2+}+\mathrm{SO}_{4}{ }^{2-}+\mathrm{Ca}^{2+}+2 \mathrm{OH} \\
\rightarrow & \mathrm{MgO}^{2+} \mathrm{SiO}_{2} \cdot \mathrm{aq}+\mathrm{CaSO}_{4} \cdot 2 \mathrm{H}_{2} \mathrm{O}+\mathrm{Ca}^{2+}+2 \mathrm{OH}^{-}
\end{aligned}
$$

Ataque por ácido sulfúrico/Sulfuric acid attack:

$$
\begin{gathered}
\mathrm{Ca}(\mathrm{OH})_{2}+\mathrm{H}_{2} \mathrm{SO}_{4} \rightarrow \mathrm{CaSO}_{4} \cdot 2 \mathrm{H}_{2} \mathrm{O} \\
\mathrm{x} \mathrm{CaO}: \mathrm{SiO}_{2} \cdot \mathrm{aq}+\mathrm{x} \mathrm{H}_{2} \mathrm{SO}_{4}+\mathrm{xH}_{2} \mathrm{O} \rightarrow \mathrm{x} \mathrm{CaSO}_{4} \cdot 2 \mathrm{H}_{2} \mathrm{O}+\mathrm{SiO}_{2} \cdot \mathrm{aq}
\end{gathered}
$$

Ataque por sulfato amónico/Ammonium sulfate attack:

$$
\begin{gathered}
\mathrm{Ca}(\mathrm{OH})_{2}+\left(\mathrm{NH}_{4}\right)_{2} \mathrm{SO}_{4} \rightarrow \mathrm{CaSO}_{4} \cdot 2 \mathrm{H}_{2} \mathrm{O}+2 \mathrm{NH}_{3} \\
\mathrm{x} \mathrm{CaO} \cdot \mathrm{SiO}_{2} \cdot \mathrm{aq}+\mathrm{x}\left(\mathrm{NH}_{4}\right)_{2} \mathrm{SO}_{4}+\mathrm{xH} \mathrm{O} \rightarrow \\
\rightarrow \mathrm{SiO}_{2} \cdot \mathrm{aq}+\mathrm{x} \mathrm{CaSO}_{4} \cdot 2 \mathrm{H}_{2} \mathrm{O}+2 \mathrm{xNH}_{3}
\end{gathered}
$$


la descomposición del CSH por iones sulfato o $\mathrm{Mg}^{2+}, \mathrm{o}$ de ambos. Tal reblandecimiento se caracteriza por una eventual pérdida completa de las propiedades cementantes, la matriz de cemento endurecida se transforma en un "mush". De nuevo, la velocidad y la forma del daño físico están relacionadas con las condiciones previamente discutidas. Ver, por ejemplo, Taylor $(23,24)$.

Independientemente de la forma arbitrariamente llamada de ataque por sulfato ("clásica" formación de yeso o etringita, reblandecimiento de la pasta, formación de la llamada etringita retrasada, formación de taumasita), la razón real para la pérdida de ciertas propiedades mecánicas es, en todos los casos, la alteración de la microestructura de la pasta. Los cambios químicos anteriormente discutidos conducen a la descomposición de algunas especies sólidas y a la formación de otras en la pastas en un momento dado. Por ejemplo, el cambio en la composición de las paredes de los poros finos (pasta entre árido o partículas de arena) puede conducir a incrementar su permeabilidad, disminuir la adherencia al árido o perder las propiedades resistentes, acelerándose entonces el proceso de deterioro. La "calidad" de tales pastas alteradas determina las propiedades "finales" físicas, químicas y mecánicas, genéricamente llamado durabilidad.

Los cambios microestructurales mas comunes causados por diversas formas de interacción con sulfato son (ver, por ejemplo $(19,25,17))$ :

- Alteración de los granos de cemento residuales (anhidros) y su sustitución por nuevos productos de reacción,

- Remoción total o parcial del hidróxido cálcico de la pasta,

- Alteración o descomposición del CSH, incluida la sustitución de $\mathrm{Ca}$ por $\mathrm{Mg}$,

- Formación y relleno de huecos por productos secundarios,

- Deposición de nuevas fases en la pasta,

- Aumento ocasional o distribución heterogénea de la porosidad, lo que conduce posiblemente a un aumento de la permeabilidad.

No es necesario decir que las alteraciones microestructurales de la matriz de pasta relacionadas con los sulfatos, no son las únicas responsables del daño químico del hormigón. Alteraciones similares de la pasta ocurren durante la carbonatación, por ataque por productos químicos agrícolas e incluso por reacción álcali-árido (aunque ASR implica reacciones preliminares con ciertas formas de sílice en los áridos). Los macroresultados de las alteraciones or $\mathrm{Mg}^{2+}$ ions, or both. Such softening is characterized by eventual complete loss of cementing properties, the hardened cement matrix transforming to a 'mush'. Again, the rate and form of physical damage relates to the conditions discussed above. See, for example, Taylor $(23,24)$.

Independent of the arbitrarily-named form of sulfate attack ("classical" gypsum or ettringite formation, paste softening, so-called delayed ettringite formation, thaumasite formation), the actual reason for the loss of certain mechanical properties is in all cases the alteration of the paste microstructure. Chemical changes discussed above lead to decomposition of some, and formation of other, solid species comprising the paste at a particular time. For example, the change in the composition of the thin pore walls (paste between aggregate or sand particles) may lead to their increased permeability, decreased bond to the aggregate or loss of tensile properties, thus accelerating the process of deterioration. The 'quality' of such altered paste determines the "ultimate" chemical and physical and mechanical properties of concrete - generically called durability.

The most common microstructural changes caused by various forms of sulfate interactions are (see, for example $(19,25,17))$ :
. Alteration of residual (unhydrated) cement grains and their infilling with new reaction products,

. Partial or complete removal of calcium hydroxide from the paste,

. Alteration or decomposition of $\mathrm{CSH}$, incl. replacement of $\mathrm{Ca}$ by $\mathrm{Mg}$,

. Formation and infilling by secondary products of hollow shells,

. Deposition of new phases within the paste,

- Occasional increase or inhomogeneous distribution of porosity, possibly leading to increased permeability.

Needless to say, microstructural alterations of the paste matrix are not responsible only for sulfaterelated chemical damage to concrete. Similar alterations to paste occur during carbonation, attack by agricultural chemicals, and even by alkali-silica reaction (though ASR involves primarily reactions with certain forms of silica in aggregate). The macroresults of such sub-microscopic alterations include increases in internal stresses and increased 
submicroscópicas incluyen aumento en la tensión interna y en la permeabilidad, eventualmente conducen a la fisuración, desprendimientos y disminución de resistencias. Es importante tener en cuenta que los sulfatos y otras formas de ataque químico en el hormigón ocurren, casi exclusivamente, en hormigones de baja calidad en términos de relación agua/material cementante, inadecuado curado y alta permeabilidad.

La identificación y la evaluación del ataque por sulfatos resultan complejos debido a las variedades de ataque químico por sulfatos y cambios

microestructurales ya discutidos. Tal y como Hooton estableció “ los operarios necesitan comprender las condiciones de exposición del hormigón y tomar las precauciones pertinentes en hormigones específicos ya que la buena calidad de los hormigones es la mejor defensa frente al ataque por sulfatos" (26).

\section{Ataque por agua de mar}

Es sabido que el deterioro del hormigón expuesto a agua de mar es causado por dos mecanismos químicos independientes: a) corrosión de las armaduras embebidas en el hormigón, y b) deterioro de la matriz del hormigón en sí misma. Mientras que la oxidación/ corrosión de las armaduras de acero, ayudada por la presencia de iones $\mathrm{Cl}^{-}$del agua de mar es probablemente el problema más importante encontrado con respecto a la durabilidad del hormigón, el daño en la matriz de cemento es un problema menor. Ambos mecanismos están íntimamente relacionados con la calidad del hormigón, especialmente con su permeabilidad a aguas que contengan especies reactivas. En los siguientes párrafos nos concentraremos en algunos aspectos del deterioro de la matriz del hormigón por agua de mar, sus similitudes y diferencias con otras formas de ataque químico, fundamentalmente con el ataque por sulfatos, y la necesidad de abordar el problema globalmente. Los principales componentes aniónicos del agua de mar son los cloruros, sulfatos y carbonatos; los cationes mas abundantes son el sodio y el magnesio. En un hormigón bien diseñado y procesado, la probabilidad de daño químico es mínima; por el contrario, un hormigón pobremente compactado y de baja densidad, es propenso a deteriorarse rápidamente.

El agua de mar es una solución muy concentrada de sulfatos $(2,7 \mathrm{mg} / \mathrm{l})$, con casi dos veces la concentración de sulfatos considerada "severa" en la Guía ACI del Hormigón Durable (27). A pesar de esta alta concentración, el ataque por sulfatos originado por el agua de mar sobre la calidad del hormigón es raro; se cree que esto es debido al efecto de los otros iones permeability, eventually leading to cracking, spalling, and decreased strength. It is important to realize that sulfate and other forms of chemical attack on concrete occur almost exclusively with concrete of low quality in terms of $w / \mathrm{cm}$, inadequate curing, and high in-field permeability.

The discussed variety of the sulfate-related chemical and microstructural changes make identification of and testing for sulfate attack complex. As correctly stated by Hooton, "there is a need for the practitioner to understand the exposure conditions of concrete and to take appropriate precautions in specifying concrete since good quality concrete is the primary defense against sulfate attack" (26).

\section{Seawater attack}

Deterioration of concrete exposed to seawater is known to be caused by two independent chemical mechanisms: a) corrosion of reinforcing steel imbedded in concrete and b) deterioration of the concrete matrix itself. Whereas reinforcing steel oxidation/corrosion, aided by the presence of $\mathrm{Cl}^{-}$ ions in seawater, is probably the most notorious problem encountered with respect to concrete durability, damage to the cementing matrix is a lesser problem. Both mechanisms are closely related to concrete quality, particularly its permeability to water containing the reactive species. In the following paragraphs we will concentrate on some aspects of concrete matrix deterioration by seawater, its similarity and differences with other forms of chemical attack, primarily sulfate attack, and the need to approach the issues globally. The primary anionic components of seawater are chlorides, sulfates, and carbonates; the most prevalent cations are sodium and magnesium. In well-designed and processed concrete, the probability of chemical damage is minimal; in contrast, poorly compacted, low-density concrete is prone to deteriorate rapidly.

Seawater is a highly concentrated solution of sulfates (ca 2,7 mg per liter), with almost twice the concentration of sulfate considered as "severe" by the ACI Guide to Durable Concrete (27). In spite of this high concentration, seawater-originated sulfate attack on quality concrete is rare; this is believed to be due to the effects of other ions present in 
presentes en agua de mar, fundamentalmente los iones cloruro $(20.000 \mathrm{mg} / \mathrm{l})$, que están considerados un instrumento en la supresión de las condiciones químicas necesarias para la formación de la etringita. De acuerdo con Mehta (28), por ejemplo, la expansión de la etringitta formada en medio de agua de mar es suprimida por la sustitución de los iones $\mathrm{OH}^{-}$por los iones $\mathrm{Cl}^{-}$. Ha de tenerse en cuenta que el hormigón es resistente a los sulfatos del agua de mar incluso en los casos en que está hecho con cemento alto en $\mathrm{C}_{3} \mathrm{~A}$. También hay que tener en cuenta que no sólo la etringita sino también la taumasita se puede formar como consecuencia de la exposición al agua de mar. La identificación de la taumasita, debido a su parecido a la etringita, ha sido a veces difícil en el pasado; entonces, algunas identificaciones de etringita descritas en la literatura podrían haber sido incorrectas.

El ataque del ácido carbónico producido por la presencia de pequeñas cantidades de $\mathrm{CO}_{2}$ disuelto en el agua de mar, está basado en la carbonatación del hidróxido cálcico libre, $\mathrm{Ca}(\mathrm{OH})_{2}$, para formar aragonito puro soluble, más que la usual forma calcítica del carbonato de calcio. Esto es considerado beneficioso cuando la carbonatación ocurre solamente en la superficie, sin alcanzar el $\mathrm{Ca}(\mathrm{OH})_{2}$ del interior del hormigón, porque ello puede disminuir la permeabilidad de la superficie del hormigón. Bajo diferentes condiciones, el $\mathrm{Ca}(\mathrm{OH})_{2}$ se puede disolver, produciéndose entonces un aumento de la permeabilidad. $\mathrm{El} \mathrm{Ca}(\mathrm{OH})_{2}$ puede también reaccionar con los cationes magnesio $(1,4 \mathrm{mg} / \mathrm{l})$ para formar brucita, $\mathrm{Mg}(\mathrm{OH})_{2}$, un mineral muy insoluble que, junto con el aragonito, se cree que densifica la superficie del hormigón, previniendo o minimizando entonces la entrada de agua de mar al interior de la estructura de hormigón. Tal reacción es un mecanismo de daño muy severo en hormigones permeables, pero mínimo en hormigones bien diseñados. Los iones magnesio pueden también reaccionar con el CSH originando silicatos magnésicos.

A nosotros nos gustaría argüir que las reacciones individuales previamente descritas no pueden ser caracterizadas fácilmente por sus efectos sobre el hormigón y que una visión mas global de los procesos tiene que ser acometida. Por ejemplo, es cierto que, basadas en condiciones ambientales locales (concentración y disponibilidad relativa de los iones en el agua; propiedades químicas y microestructurales de la pasta de cemento en la matriz del hormigón; temperatura, etc.), hay reacciones en competencia entre los iones $\mathrm{Mg}^{2+}$, sulfato y carbonato (capaces de reaccionar con el $\mathrm{Ca}^{2+}$ originado por el $\mathrm{Ca}(\mathrm{OH})_{2}$ y $\mathrm{CSH}$ ) y que los iones $\mathrm{Cl}^{-}$no solamente eliminan la presencia de iones $\mathrm{OH}^{-}$cambiando entonces el $\mathrm{pH}$, sino que, debido a este cambio de $\mathrm{pH}$, también influye seawater, primarily chloride ions (ca $20.000 \mathrm{mg}$ per liter), that are considered to be instrumental in suppressing the chemical conditions needed for formation of ettringite. According to Mehta (28), for example, expansion of ettringite formed in a seawater environment is suppressed by essential replacement of $\mathrm{OH}^{-}$ions by $\mathrm{Cl}$ ions. Please note that quality concrete is resistant to seawater sulfates even in cases when it is made with high- $C_{3} A$ cement. It should also be noted that not only ettringite but also thaumasite may form as a result of seawater exposure. Identification of thaumasite, because of its similarity to ettringite, has been somewhat difficult in the past; therefore some of the ettringite identifications reported in the literature may have actually been misdirected.

Carbonic acid attack, enabled by the presence in seawater of small amounts of dissolved $\mathrm{CO}_{2}$, is based on carbonation of free calcium hydroxide, $\mathrm{Ca}(\mathrm{OH})_{2}$, to form purely-soluble aragonite rather than the usual calcitic form of calcium carbonate. This is considered beneficial if the carbonation occurs only at the concrete surface, without reaching the $\mathrm{Ca}(\mathrm{OH})_{2}$ within the concrete, because it may decrease the permeability of the concrete surface. Under different conditions, the $\mathrm{Ca}(\mathrm{OH})_{2}$ may dissolve, thus leading to increased permeability. $\mathrm{Ca}(\mathrm{OH})_{2}$ can also react with magnesium cations (ca 1,400 $\mathrm{mg}$ per liter) to form brucite, $\mathrm{Mg}(\mathrm{OH})_{2}$, a highly insoluble mineral which, together with aragonite, is believed to densify the concrete surface, thus preventing or minimizing the ingress of seawater into the concrete structure. Such reaction is a very severe damage mechanism in permeable concrete, but minimal in well designed concrete. $\mathrm{Mg}^{2+}$ ions may also react with $\mathrm{CSH}$ leading to formation of magnesium silicates.

We would like to argue that the above individual reactions cannot easily be characterized as to their effect on concrete and that a more global look at the processes has to be undertaken. For example, it is certain that, based on the local environmental conditions (concentration and relative availability of ions in the water; chemical and microstructural properties of the cement paste in the concrete matrix; temperature, etc.), there is a chemical "competition" between the $\mathrm{Mg}^{2+}$, sulfate and carbonate ions (capable of reacting with the $\mathrm{Ca}^{2+}$ originating from $\mathrm{Ca}(\mathrm{OH})_{2}$ and $\mathrm{CSH}$ ) and that the $\mathrm{Cl}^{-}$ions not only suppress the presence of $\mathrm{OH}^{-}$ions, thus changing the $\mathrm{pH}$ but, because of this $\mathrm{pH}$ change, they also influence the availability or reactivity of paste 
sobre la disponibilidad y reactividad de los componentes de la pasta, por ej. del $\mathrm{C}_{3} \mathrm{~A}$, permitiendo posiblemente la formación de la sal de Friedel más que la etringita.

Como un ejemplo de la complejidad de la situación: Thomas y colaboradores (29) describieron que el daño fundamental de hormigones expuestos al agua de mar fue el reblandecimiento de la superficie de la matriz, causado por la descalcificación del CSH y la formación de aragonito, silicato magnésico y taumasita. La etringita fue únicamente identificada debajo de la capa superficial; el yeso se encontró en ambas posiciones, dentro y debajo de la superficie. La brucita no fue detectada. Otros autores encuentran diferentes combinaciones de productos de reacción, dependiendo de las condiciones medias de exposición del hormigón y posiblemente del procedimiento de ensayo.

Entonces, como en el caso del ataque por sulfatos, los mecanismos físico-químico-microestructurales por ataque del agua de mar son complejos y esto tiene que ser tenido en cuenta a la hora de desarrollar métodos de ensayo y normas. No obstante, hay que mencionar que el ataque por agua de mar es mínimo en hormigones densos, adecuadamente elaborados; bajo tales condiciones la complejidad de las reacciones es realmente de escaso interés práctico.

\section{ENSAYOS DE DURABILIDAD}

No es adecuado describir aquí con detalle los diversos ensayos, tanto destructivos como no destructivos, que son -o pueden- ser usados para evaluar las condiciones de una estructura de hormigón. Estos ensayos van desde los métodos tradicionales, como extracción de testigos, microscopía óptica, etc., hasta las técnicas más modernas tales como el uso de la sofisticada microscopía electrónica de barrido, ensayos rápidos de permeabilidad al ion cloruro, ensayos de ultrasonido o ensayos de radar. Sin embargo, todos estos ensayos tienen una cosa en común: evalúan las propiedades del hormigón en un único momento. Esto a menudo lleva a dificultades y ambigüedades en la interpretación (para desesperación de propietarios y constructores, pero para deleite de los abogados).

Lo más importante es que los ensayos llevados a cabo en un instante determinado no pueden ser usados para responder las preguntes realmente importantes

- ¿El hormigón original estaba por debajo de la norma? - ¿Cómo se comportará el hormigón en el futuro? ¿Es esencialmente estable, o se continuará deteriorando? - ¿Cuál es la vida proyectada de la estructura?

- ¿Puede el hormigón ser satisfactoriamente reparado? components, for example $C_{3} A$, thus possibly enabling formation of Friedel's salt rather than ettringite.

As an example of the complexity of the situation: Thomas and coworkers (29) reported that the primary damage to concrete being exposed to seawater was surface matrix softening, caused by decalcification of $\mathrm{CSH}$ and formation of aragonite, magnesium silicate and thaumasite. Ettringite was detected only below the surface layer; gypsum was found both within and below the surface. Brucite has not been detected. Other authors found different combinations of reaction products, depending on the overall conditions of concrete exposure and, possibly, test procedure.

Thus, as was the case with sulfate attack, the physical-chemical-microstructural mechanisms of seawater attack are complex and this has to be taken into consideration in development of test methods and standards. It remains a fact, however, that seawater attack is minimal in properly produced, dense concrete; under such conditions the complexity of the reactions is actually of little practical interest.

\section{TESTING FOR DURABILITY}

It is not appropriate here to describe in detail the various tests, both destructive and non-destructive, which are or can be used to evaluate the condition of a concrete structure. These tests range from the traditional methods such as coring, rebound hardness tests, optical microscopy, and so on, to more modern techniques such as the use of sophisticated scanning electron microscopy, rapid chloride-ion permeability tests, pulse-echo testing, or ground penetrating radar. However, all of these tests have one thing in common: They evaluate the properties of the concrete at a single point in time. This often leads to difficulties and ambiguities in interpretation (to the despair of owners and builders, but to the delight of the legal profession)!

Most importantly, tests carried out at a single point in time cannot be used to answer the really important questions:

-Was the original concrete substandard? -How will the concrete behave in the future? Is it essentially stable, or will it continue to deteriorate? -What is the projected life of the structure? -Can the concrete be repaired satisfactorily? 
Para responder estas preguntas, ninguno de estos ensayos es, en sí mismo, adecuado. Se necesita monitorizar el comportamiento de estructuras de hormigón de un modo regular (e incluso continuo), de manera que podamos determinar la velocidad de cambio en las propiedades de interés. Entonces, para monitorizar adecuadamente estructuras de hormigón, nosotros tenemos que instaurar un programa que comience en el momento en que el hormigón es fabricado y que continúe durante la vida de la estructura. Aun cuando esto puede conllevar costes importantes, permitiría las oportunas estrategias de reparación y mantenimiento, lo cual ahorraría dinero a largo plazo. Los recientes desarrollos en estructuras de hormigón inteligente ("smart"), con equipos de monitorización colocados in situ es un paso en esta dirección.

Para complicar más la cuestión, se debe recordar que el deterioro del hormigón puede implicar a los sistemas cementantes, los áridos o las armaduras de acero. Además, el deterioro puede ser debido a una combinación de factores físicos y químicos. Entonces es muy improbable que se pueda usar un único método de ensayo para identificar todos los problemas posibles. Idealmente, un conjunto de métodos de ensayo debería ser empleado, en un período de tiempo, para conseguir un diagnóstico verdadero. Esto se completaría con el uso de modelos apropiados (tal como aquél, propuesto por Marchand (30)) para ayudar en la predicción de la vida proyectada de una estructura.

Virtualmente todos los mecanismos de deterioro del hormigón se manifiestan por fisuración o descamación visible, quizás acompañado por alguna eflorescencia. Entonces, incluso después de que todos estos ensayos se hayan hecho, uno tiene todavía el recurso de usar el juicio del ingeniero (sentido común). El problema real para el ingeniero es determinar la causa del daño, si éste perjudica el uso apropiado de la estructura, si es probable que se deteriore más y qué se puede hacer (si es que hay algo que se pueda hacer).

\section{CONCLUSIONES}

Asegurar la durabilidad de estructuras de hormigón es un problema complejo que requiere una cuidadosa atención en la selección de los materiales, manejo, puesta en obra y curado. Es decir, nosotros tenemos que adoptar un enfoque holístico para la construcción en hormigón como proclamaron Mehta [4] y otros. Esto requerirá un cambio en la mentalidad de los ingenieros en la práctica diaria y en el modo en el cual nosotros enseñemos a las futuras generaciones de ingenieros.
To answer these questions, not one of these tests is, in itself, adequate. We need to monitor the behavior of concrete structures on a regular (or even continuous) basis, so that we can determine the rate of change in the properties of interest. Thus, to monitor concrete structures properly, we must institute a program which starts at the time the concrete is cast, and which continues for the life of the structure. While this may involve significant costs, it would permit timely maintenance and repair strategies, which will save money in the long run. The recent developments in constructing "smart" concrete structures, with monitoring equipment cast in place, is a step in this direction.

To complicate the issue further, it must be remembered that concrete deterioration may involve the cementitious system, the aggregates or the reinforcing steel. Further, the deterioration may be due to a combination of physical and chemical factors. Thus, it is highly unlikely that any single test method can be used to identify all of the possible problems. Ideally, a variety of test methods should be employed, over a period of time, to get a true picture. This should be supplemented by the use of appropriate models (such as the one, proposed by Marchand (30)) to aid in prediction of the projected life of the structure.

Virtually all concrete deterioration mechanisms are manifested by visible cracking or spalling of the concrete, perhaps accompanied by some efflorescence. Thus, even after all of the testing has been carried out, one must still resort to the use of engineering judgment (i.e., common sense). The real problem for the engineer is to determine the cause of the damage, whether it impairs the proper use of the structure, whether it is likely to get worse, and what (if anything) can be done about it.

\section{CONCLUDING REMARKS}

Ensuring the durability of concrete structures is a complex problem, requiring careful attention to selection of materials, handling, placing and curing. That is, we must adopt the "holistic" approach to concrete construction as advocated by Mehta [4] and others. This will require a change in the mind-set of the engineers in current practice, and in the way in which we train future generations of engineers. 


\section{BIBLIOGRAFÍA}

(1) Shah, S.P., Wang, K. and Weiss, W.J., 2000. Mixture Proportions for DurableConcrete-Challenges and Changes, Concrete International, Vol. 22, No. 9, pp 73-78.

(2) Gebhardt, R.N., 1995. Survey of North American Portland Cements: 1994, Cement, Concrete and Aggregates, Vol. 17, No. 2, pp 145189.

(3) Neville, A., 2001. Consideration of Durability of Concrete Structures: Past, Present and Future, Materials and Structures (RILEM), Vol

34,No.236, pp 114-118.

(4) Mehta, P.K. and Burrows, R.W., 2001. Building Durable Structures in the $21^{\text {st }}$ Century. Concrete International, Vol. 23, No. 3, pp 5763.

(5) Nehdi, M., 2001. Ternary and Quaternary Cements for Sustainable Development, Concrete International, Vol. 23 , No. 4, pp 35-42.

(6) Kreijger, P.C., 1984. The Skin of Concrete: Composition and Properties. Materials and Structures, Vol. 17, No. 100, pp $275-283$.

(7) Bentur, A. and C. Jaegermann, 1991. Effect of Curing and Composition on the Properties of the Outer Skin of Concrete. Journal of Materials in Civil Engineering, Vol. 3, No. 4,pp 252-262.

(8) Cairns, J., 1999. Enhancement in surface quality of concrete through use of controlled permeability formwork liners. Magazine of Concrete Research, Vol. 51, No. 2, pp 73-86.

(9) Wilson, D., 1994. Controlled permeability formwork. Concrete, Vol. 28, No. 2, pp 20-22.

(10) TRB, 1996. Transverse Cracking in Newly Constructed Bridge Decks. NCHRP Report 380, Transportation Research Board, Washington, DC, USA.

(11) Lerch, W., 1957. Plastic Shrinkage. Journal of the American Concrete Institute, Vol. 53, No. 8, pp 797-802.

(12) ACI, 1997. Standard Practice for Curing Concrete. ACI Manual of Concrete Practice, American Concrete Institute, Detroit, Michigan, USA, ACI 308-92.

(13) Saeles, C.A. and K.C. Hover, 1988. Influence of Mix Proportions and Construction Operations on Plastic Shrinkage in Thin Slabs. ACI Materials Journal, Vol. 85, No. 6, pp 495-504.

(14) Samman, T.A., W.H. Mirza and F.F. Wafa, 1996. Plastic Shrinkage Cracking of Normal and High-Strength Concrete: A Comparative Study. ACI Materials Journal, Vol. 93, No. 1, pp 36-40.

(15) Soroka, I. and D. Ravina, 1998. Hot Weather Concreting with Admixtures. Cement and Concrete Composites, Vol. 20, No. 2-3, pp 129136.

(16) Almussalam, A.A., M. Maslehuddin, M. Abdul-Waris, F.H.Dakhil and O.S.B. Al-Amoudi, 1999. Plastic shrinkage cracking of blended cement concretes in hot environments. Magazine of Concrete Research, Vol. 51, No. 4, pp 241-246.

(17) Skalny, J. and Marchand, J., 2001, Sulfate Attack on Concrete Revisited, in Proceedings of the Kurdowski Symposium, Cracow, June 20-21,2001.

(18) Hime, W.G. and Mather, B, [2000], "Sulfate Attack," or is it?, Cement and Concrete Research, Vol. 29, 789-791.

(19) Diamond, S. and Lee, R.J. [1999], Microstructural Alterations Associated With Sulfate Attack in Permeable Concretes, in Materials Science of Concrete Special Volume: Sulfate Attack Mechanisms (J. Marchand and J. Skalny, Eds.), The American Ceramic Society, 123174.

(20)Corr, D.J., Monteiro, P.J.M., Kurtis, K.E. and DerKiureghian, A., 2001. Sulfate Attack of Concrete: Reliability Analysis, ACIMaterials Journal, Vol. 98, No. 2, pp 99-104.

(21) Gartner, E.M. and Gaidis, J.M. [1989], Hydration Mechanisms I, in Materials Science of Concrete I (J. Skalny, Ed.), The American Ceramic Society, Westerville, $\mathrm{OH}, 95-125$.

(22) Scherer G. W. [1999], Crystallization in Pores, Cement and Concrete Research, Vol. 29, 1347-1358.

(23) Taylor, H.F.W. [1994], Sulfate Reactions in Concrete-Microstructural and Chemical Aspects, in Cement Technology (E.Gartner and H. Uchikawa, Eds.), The American Ceramic Society, Westerville, OH, 61-78.

(24) Taylor H.F.W. [1997], Cement Chemistry, $2^{\text {nd }}$ edition, Thomas Telford Publishing, 1997.

(25) Diamond, S. [2000], Microscopic Features of Ground Water-Induced Sulfate Attack in Highly Permeable Concretes, presented at the ACI/CANMET mtg., Barcelona, Spain, June 2000.

(26) Hooton, R.D. [1999], Are Sulfate Resistance Standards Adequate?, , in Materials Science of Concrete Special Volume: Sulfate Attack Mechanisms (J. Marchand and J. Skalny, Eds.), The American Ceramic Society, 357-366.

(27) ACI [1997], ACI Guide for Durable Concrete, American Concrete Institute, Detroit, Michigan, USA.

(28) Mehta, P.K. [1991], Concrete in the Marine Environment, Elsevier Applied Science, London

(29) Thomas, M.D.A. [1999], Sulfate Attack in a Marine Environment, in Materials Science of Concrete Special Volume: Sulfate Attack Mechanisms (J. Marchand and J. Skalny, Eds.), The American Ceramic Society, 301-314.

(30) Marchand, J., 2001. Modeling the Behavior of Unsaturated Cement Systems Exposed to Aggressive Chemical Environments, Materials and Structures (RILEM), Vol. 34, No. 230, pp. 195-200.

\section{Nota de Redacción}

El Comité de redacción agradece a $\mathrm{D}^{\mathrm{a}}$. $\mathrm{M}^{\mathrm{a}}$ Teresa Blanco la traducción del artículo al español y la revisión técnica del mismo. 